\title{
COMPREHENSIVE ANALYSIS OF REGULATORY IMPACTS ON PERFORMANCE OF SLOVAK PENSION FUNDS
}

\author{
Mário PAPÍK (iD), Lenka PAPÍKOVÁ (ic \\ Department of Economics and Finance, Faculty of Management, \\ Comenius University, Bratislava, Slovakia
}

Received 28 July 2020; accepted 29 January 2021

\begin{abstract}
Standard pay-as-you-go pension system is facing long-term and short-term sustainability challenges in several countries. Possible replacement of standard pension system might be in a form of private pension savings. Private pension savings are meaningful only if they provide sufficiently high returns. The aim of this manuscript is to analyse performance of Slovak pension funds and factors impacting this performance, especially government interventions. This manuscript is focused on enhanced Carhart four-factor model, Bollen and Busse four-factor model, and Fama and French five-factor model based on 23 pension funds from Slovakia from period starting September 2012 and ending September 2019. These models have been extended by other variables describing bond market factors and impact of regulatory interventions on performance of pension funds. Results of analysis have proved that legislative interventions have impact on performance of analysed pension funds. Each legislative intervention has caused average daily yield to decrease by about $0.01 \%$ to $0.03 \%$. Findings described in this manuscript can contribute to better knowledge of pension funds for both contributors who need to decide whether to participate in the second pillar or not, as well as for regulators who develop legislation measurements in this area.
\end{abstract}

Keywords: pension funds, investment performance, Carhart four-factor model, Bollen and Busse four-factor model, Fama and French five-factor model, regulatory intervention, bond market factors, equity market factors, Central and Eastern Europe.

JEL Classification: D53, G12, G14, G23, G28.

\section{Introduction}

Changes in demographic trends and aging population have negatively affected multiple pension systems across Europe. The pay-as-you-go system (PAYG) has been inevitably transformed in several countries into private pension savings systems in order to ensure the sustainability of pension payments in the future. More than thirty countries - predominantly in Central and Eastern Europe (CEE) and Latin America - partly replaced their public pension systems with mandatory private retirement accounts managed by

\footnotetext{
${ }^{\star}$ Corresponding author. E-mail: mario.papik@gmail.com
} 
financial industry during period of mid-1990's and early 2000's (Égert , 2012; Guardiancich, 2013; Madrid, 2003).

Transition from centrally planned economies to market economies triggered social changes and restructure of labour markets especially in CEE. Shifts in structure of labour demand increased pressure for early retirement and raised concerns about pension system financing. Decreasing fertility levels and increasing life expectancy have accentuated aging of population (Bielawska et al., 2017). Proportion of worldwide population aged 60 and more would grow from approximately $19 \%$ in 2005 to $36 \%$ in 2050. Percentage of 60 plus age group would reach 38\% in Central Europe, 34\% in South-Eastern Europe and 36\% in the Baltic States by 2050 (Cerami, 2011). Same situation occurs in Slovakia with birth rate decreasing from 2.1 child in 1990 to 1.3 child in 2000 along with increased life expectancy (Chovancová \& Bačišin, 2005; Mitková, 2016).

All this evidence indicates that pension systems in CEE countries might have problems with paying out pensions guaranteed by state in few decades time. Pension systems hence face both short-term and long-term sustainability challenges. Many CEE countries introduced structural reforms shifting towards multi-pillar pension systems with fully funded components (Bielawska et al., 2017). Several studies indicate that some countries have performed also pension fund reform reversals e.g. decreased contribution payments or system switch from mandatory to optional (Casey, 2014; Drahokoupil \& Domonkos, 2012; Naczyk \& Domonkos, 2016; Price \& Rudolph, 2013). Josifidis et al. (2015) shows that financial crisis in 2008 slowed down intensity and dynamics of pension systems reforms in European Union. Financial crisis and unstable political decisions led to concentration of pension funds in market such as in Baltic countries (Medaiskis \& Gudaitis, 2017).

Slovakia, like other CEE countries, is facing challenges regarding its pension system due to negative trends in demography and complicated labour migration from foreign countries (Saxunová \& Chorvatovičová, 2018). Increased number of domestic contributors and also foreign workers could both contribute to the pension system so that it becomes more financially sustainable in the future. On January 1, 2005, pension reform with fundamental influence on the function of pension system has been introduced in Slovakia. This reform has resulted in transformation of one-pillar pension system with set PAYG contributions into a pension system with three individual pillars (Orenstein, 2011).

Since 2003, Slovak pension system has been created by three pillars. The first pillar consists of compulsory pension insurance guaranteed by the state based on continuous payas-you-go (PAYG) system. All citizens reaching mandatory retirement age are entitled to payment from the first pillar. The second pillar and the third pillar represent the old-age pension savings funded by capitalization and managed by pension management companies. The second pillar represents private retirement savings funded by social security contributions from income. The third pillar represents voluntary private pension saving depending solely on contributor.

Rules of Slovak second pillar have been modified several times during period from 2008 to 2014. As stated by Papík and Kajanová (2016), legislative interventions have modified percentage of contributions from 9\% (2005) to 4\% (2009). Legislation now defines annual 
increase of $0.25 \%$ from $4 \%$ in 2016 to $6 \%$ in 2024 . The second pillar is also no longer mandatory for all young citizens entering labour market after 18 years of age. The second pillar is now voluntary with multiple periods when contributors were allowed to leave or return from private pension savings to the PAYG system only.

Slovak pension funds have undergone several changes. These changes include obligation to guarantee nominal value of a pension fund from 2009 and 2012 as a measure against financial crisis. Another change is the categorization of existing pension funds from growth to equity pension funds, conservative to bond pension funds, and balanced to mixed pension funds. During this period, most people have been also automatically transferred from growth funds to conservative funds as a result of government intervention.

Despite many government interventions, pension funds allow the first pillar of the pension system to decrease its costs and to capitalize savings at the financial markets and thus ensure sustainable development of public finances. While retirement pay has been increased between 2009 and 2018 by an annual average of $3.4 \%$, stock markets in the same period increased on average by $7.7 \%$ per annum as measured by the index Euronext 100 .

The aim of this manuscript is to analyse performance of Slovak pension funds and factors impacting their performance, especially government interventions. To successfully fulfil the aim of this manuscript, Slovak pension system has been analysed. Slovak pension fund system has experienced many reforms like movement of contributors among pension funds, contributors leaving the second pillar or changes in contribution rate. All of these adjustments to pension system might have led to changes in its functioning and might have impacted performance and return of pension funds. In addition to the aim of this manuscript, this manuscript will also analyse impact of adjustments onto the pension fund performance. Reforms of pension system in post-communist countries of Central and Eastern Europe has taken place in approximately same time and therefore, literature review in this manuscript focuses on the most important studies about pension fund performance mainly from the CEE region. Since Slovak pension funds have had considerable portion of their portfolios in bonds which is the result of regulatory interventions from 2008 and 2009. Due to considerable portion of bonds in portfolios, this manuscript has tested impact of government regulations on fund performance models based on equity market factors as well as on bond market factors. Due to this reason, literature review of this manuscript focuses on existing studies applying different portfolio performance models and approaches. This has allowed application of proper methodology for different pension fund types. Unlike previous studies, this manuscript applies Carhart, Bollen and Busse and Fama and French models on Slovak pension funds which has not been analysed before. Furthermore, contrary to other studies, this manuscript combines all three aspects impacting fund performance: equity market factors, bond market factors and regulatory factors.

Structure of this manuscript is organised as follows: Section 1 contains literature review of relevant existing studies. Section 2 describes research used methodology related to measuring of portfolio performance. Section 3 provides description statistics, results of developed models and discussion. Last section represents concluding remarks. 


\section{Literature review}

Pension fund savings have short history in CEE region - pension reforms took place during 1990's and first half of 2000's. Therefore, there are only few studies analysing performance of the second pillar managed in private equity portfolios. Study of Antolin (2008) compares performance of pension funds across OECD, Latin America and CEE countries. Antolin (2008) has determined that performance of pension funds is lower compared to market performance in these regions. Different results have been proved on a sample of $26 \mathrm{Lithu}-$ anian pension funds, with pension funds achieving slightly higher yield when compared to benchmark yield along with significantly lower volatility (Kabašinskas et al., 2017). Better performance of four mandatory pension funds compared to that of benchmark has been initially confirmed also in Croatia (Matek et al., 2015), although recent studies have shown rather weak performance of these pension funds (Draženović et al., 2019). Draženović et al. (2019) has proved that, between 2015 and 2018, only 5 out of 12 compulsory pension funds have achieved comparable or better returns than benchmark. Furthermore, another study has proved, that for 10 out of 12 analysed pension funds in Poland, their portfolio managers have been unable to adjust managed portfolio to take advantage of market trends, thereby underperforming during period from February 2014 to December 2016 (Kurach, 2019).

Meštan et al. (2016) has studied low yields of actively managed pension funds in Slovakia. Passively managed pension funds have provided interesting risk-adjusted returns to contributors despite their short existence. These funds are available in Slovakia since 2012. Chovancová et al. (2019) has studied relationship between performance of pension fund and ratio of assets under management to gross domestic product. Chovancová et al. (2019) has confirmed that pension funds are significantly correlated with trends on bond market.

Pension funds are largely regulated by legislation unlike mutual funds. This regulation includes obligation of this pension scheme for contributors in countries with several pension pillars. Although there has not been available data for duration of more than 10 years to study performance of private pension savings at that time, Antolin has proved that legislative interventions indeed impose negative impact on fund performance (Antolin, 2008). Study on a two-pillar pension system in Poland has been conducted recently by Kurach et al. (2020). This study has indicated that government regulations might indeed significantly reduce the opportunity to minimize shortfall risks which has direct impact on savings of contributors in this pillar and their future retirement pay.

Boon et al. (2018) has proved that performance of pension funds decreases with each government intervention for 331 pension funds from the USA, 181 from Canada and 27 from Netherlands. Similarly, Witkowska et al. (2019) has proved that legislative intervention is usually followed by significant increase in portfolio risk which is expressed as increased volatility in post-legislative intervention period. Legislation interventions also affect performance of pension funds in CEE, specifically in Croatia (Draženović et al., 2019).

Several studies have focused on performance of different portfolio types. For example, Blake et al. (2002), Bauer and Kicken (2008) and Khorana et al. (2007) have confirmed differences between performance of fixed income funds and equity funds. Alda and Ferruz (2012) have proved that Fama and French three factor model and Carhart models may not 
explain performance of pension funds with significant proportion of fixed income assets. Bond market factors have been described and analysed by Fama and French (1993) in their three-factor model but impact of these factors on portfolio performance has not been confirmed. Nevertheless, these factors have been used by Choi and Kim (2018) and Bektić et al. (2019), who have extended the Fama and French five-factor model with variables describing returns from fixed income assets.

Disadvantage of many above-mentioned fund studies in CEE is that analysis and comparisons of performance comparison is conducted through Sharpe ratio (Sharpe, 1994), CAPM (Sharpe, 1964), Sortino ratio (Sortino \& Van Der Meer, 1991), Jensen's alpha (Jensen, 1968) or Treynor ratio (Treynor, 1965). Recent studies such as those comparing performance of green funds with that of standard funds (Leite \& Cortez, 2014; Silva \& Cortez, 2016; MartiBallester, 2019, 2020), or studies focusing on comparative performance of funds in regions other than CEE (Adami et al., 2014; Boubakri et al., 2016; Sha \& Gao, 2019) use Fama and French three-factor or five-factor models (Fama \& French, 1993, 2015) or Carhart's model (Carhart, 1997). Analysis of funds data from CEE using this methodology would be interesting as well. Comparison between CAPM or Fama and French models proves better results for Fama and French models (Galinienè \& Butvilas, 2010; Kaya, 2020). Moreover, comparison between Carhart's model and Fama and French five-factor model proves better results for Fama and French model for Pakistan (Ali et al. 2019).

\section{Research methodology}

Research methodology along with more information about data samples and used statistical techniques are in following chapters.

\subsection{Sample and data preparation}

Aim of this manuscript is to analyse performance of Slovak pension funds and factors impacting this performance. Six identified pension fund management companies in Slovakia manage 23 pension funds. Dataset includes data from 2009 to 2019. Pension funds included in dataset have been categorised into four groups: equity (6), mixed (5), bond (6) and index (6) funds. Sample size is comparable with that of other studies from the CEE region or Balkan region (Draženović et al., 2019; Kabašinskas et al., 2017; Kurach, 2019; Matek et al., 2015; Meštan et al., 2016).

Equity funds invest mostly into stocks and shares in mutual funds. Equity funds along with index funds are considered the riskiest with highest expected returns. Mixed funds own combination of government and corporate bonds and equity assets such as stocks and shares in other funds and provide stable returns with corresponding level of risk. Bond funds consist purely of government or corporate bonds and money market transactions which are less risky with lower expected returns. Index funds are the only passively managed funds with lower management fee for contributors than actively managed pension funds. Index funds do not have any performance fee. Slovak index funds are mostly related to MSCI World Index and are considered along with equity funds among the riskiest with highest expected returns. 
Data consisting of daily actual value of pension units of pension funds has been collected for period from $1^{\text {st }}$ January 2009 till $30^{\text {th }}$ September 2019 from the National Bank of Slovakia. Daily actual value of pension unit is calculated as net asset value (NAV) to total number of contributors. Calculated actual value of pension unit has been then indexed so that sum of actual pension units of all pension funds has been 1 in the beginning of analysed period.

Due to legislation interventions obligating funds to guarantee nominal value of contributions throughout January 1, 2009 to August 31, 2012, this period has been excluded from dataset. All actively managed pension fund types had identical asset structure during that time and there has not been any statistically significant difference between amount of bonds and equity funds and bond and mixed funds (Papík \& Kajanová, 2016). Pension fund management companies have used this approach to protect nominal value of contributions and to guarantee invested nominal value. This has led pension funds to invest into less risky assets like government bonds or fixed-term deposits. Therefore, this period has been excluded from analysed period of this manuscript.

Daily total return of capitalization-weighted European stock market index Euronext 100 has been obtained from Bloomberg database. Euronext 100 includes 100 largest and most liquid stocks (blue chip segment of listed stocks) traded at Euronext exchange. Values for daily market size, daily book to market ratio, daily momentum risk factors, daily profitability factor and daily investment factor for the European market have been collected from Kenneth R. French's data library. Daily risk free rate has been defined as daily yield of 1-month Euribor rate of the European Central Bank. Daily yield of 1-month Euribor rate is an alternative to American non-risk rate of US Treasury bills. Daily yield of AAA Rated 10-Year Eurozone Central Government Bonds and yield of AAA Rated 10-Year Corporate Bonds have been obtained from Bloomberg terminal. Information about asset structure of pension funds has been collected from annual reports and aggregated for each kind of pension fund. All daily data has been obtained for period from $1^{\text {st }}$ September 2012 to $30^{\text {th }}$ September 2019 and annual reports have been collected from 2012 to 2018.

Data related to regulatory interventions and marching orders has been obtained from the National Bank of Slovakia. These data include information about government regulations like possibility to leave private pension system or percentage of contribution to pension fund system.

\subsection{Enhanced model with regulatory and bond market factors}

As financial markets have significantly changed since the 1960 's, also other multifactor models impacting portfolio performance have been used besides capital asset pricing model (CAPM) which provides little information about average returns of portfolios. Instead, Carhart four-factor model, Bollen and Busse four-factor model and Fama and French five-factor model contain wide variety of profit-impacting factors, e.g. market factor, managerial abilities or profitability. Cremers et al. (2012) report statistically significant nonzero alphas in various asset pricing models indicating likelihood of alternative factors not captured by common multi-factor models.

Instead of identification of a variable that systematically describes missing variable in multi-factor models, it is necessary to identify a variable that randomly influences markets. 
As an alternative to cyclical market view, there is view where economy is inherently unstable and hit by shocks that are responsible not for the cycles as such but rather for their unpredictability (Portier, 2018).

Two assumptions to detect market instability interactions are: first assumption states that markets are globally stable but locally instable, which does not allow detection of global variable for market instability, but some variables for certain local markets might exist. Second assumption is that instability of system cannot come from the system itself but comes from the outside. Such an example might be regulations and state interventions.

Slovak private pension system can be defined as a closed system. Contributors who once joined the system cannot leave it in the future. Due to government interventions, system in Slovakia has been open multiple times for contributors to leave the second pillar. Second type of intervention is percentage of contribution, which has been changed several times during analysed period. Contribution to the second pillar is mandatory for each contributor who has existing contract with any second pillar pension fund management company. Rate of contribution is defined by the government (Janać et al., 2016). This rate has been defined as $4 \%$ of the gross salary of contributor until 2016 followed by annual increase of $0.25 \%$ until 2024. In 2024, contribution rate into the second pillar should equal $6 \%$ of the contributor's gross salary. Since no legislative interventions have been made for fund management fees in Slovakia during analysed period, this variable has not been included.

Apart from stock market factors describing three-factor model, Fama and French (1993) have also studied variables connected to corporate bond market: term premium (TERM) and default premium $(D E F)$. As Slovak pension funds include significant portion of fixed income assets, index funds which do not include this portion have been tested without variables TERM and DEF.

Since Fama and French (1993) study proved that slopes of corporate bond returns are like the slopes of stocks, they assumed that stocks share almost all the variation in high-grade corporate bond returns leading them to exclude corporate bond factors from their model. Study of Choi and Kim (2018) pointed out that anomaly variables of bond portfolios are too significant to be described by their hedge ratios with respect to the equity portfolios of the same issuers. Repeated application of Fama and French five-factor variables to multifactor models has confirmed statistical significance of TERM and DEF variables. Similar results were achieved also by Bektić et al. (2019) who studied extended Fama and French five-factor model on the European market and who has proved statistical significance of these factors. Since latest studies indicate low tracking error on the European markets, this manuscript has extended all analysed models by regulatory impact variables, but also by bond market factors TERM and DEF. Even though concept of government bond factors application is not as widely applied as concept of equity factors, recent studies indicate existence of significant government bond factors which should be considered in developed models (Bektić et al., 2020).

Carhart four factor-model (1997) is based on Fama and French three-factor model with additional factor developed by Jegadeesh and Titman's (1993) one-year momentum variable. This model has been recently applied in studies by Alam and Ansari (2020) in order to detect size timing abilities in India fund market. In the study of Azizi et al. (2020) this model has 
achieved higher predictive ability in prediction of portfolio performance than other models such as Fama and French three factor model (1993), Fama and French five factor model (2015), Brousseau five factor model (2015) or Roy and Shijin six-factor model (2018).

This manuscript extends Carhart four-factor model (1) and has form:

$$
\begin{gathered}
r_{p, t}-r_{f, t}=\propto_{i}+\beta_{i, M K T}\left(r_{m, t}-r_{f, t}\right)+\beta_{i, S M B} S M B_{t}+\beta_{i, H M L} H M L_{t}+\beta_{i, M O M} M O M_{t}+ \\
\beta_{i, S L O} S L O_{t}+\beta_{i, C O N T} C O N T_{t}+\beta_{i, T E R M} T E R M_{t}+\beta_{i, D E F} D E F_{t}+\varepsilon_{i, t},
\end{gathered}
$$

where $r_{p, t}$ represents daily total return $r_{p, t}$ for pension fund $p$ in time $t, r_{f, t}$ is daily risk-free rate represented by 1-month Euribor. Daily risk-free rate is a yield an investor would expect to receive from absolutely risk-free investment. Variable $r_{m, t}$ represents total daily return of European stock market index Euronext 100. Variable $S M B_{t}$ represents daily market size calculated as the difference between return of small and large cap stocks, $H M L_{t}$ represents daily book to market ratio calculated as the difference between return of high book-tomarket and low book-to-market stocks and $M O M_{t}$ is the daily momentum risk factor. Some studies have not proved momentum variable $M O M_{t}$ as statistically significant compared to original Fama and French three-factor model (Tonks, 2005; Clare et al., 2010). However, when applied to data from CEE region, this model achieved the highest explanatory ability for cross-sectional returns and is well-suited for asset pricing in CEE (Zaremba et al., 2019).

Variable $S L O_{t}$ represents dummy variable which identifies periods when pension system has been open and contributors allowed to leave the system. Variable $C_{0 N T_{t}}$ stands for percentage of contribution contributed from gross salary.

Variable TERM $M_{t}$ represents term premium factor as the difference between return of AAA Rated 10-Year Eurozone Central Government Bond and return on 1-month Euribor rate. Calculation of term premium factor corresponds with risk-free rate similar to rate used by Fama and French (1993). Variable $D E F_{t}$ is also aligned with Fama and French (1993) and is expressed as default premium factor. It is calculated as the difference between AAA Rated 10-Year Corporate Bond and AAA Rated 10-Year Eurozone Central Government Bond.

Variables $\beta_{i, M K T}, \beta_{i, S M B}, \beta_{i, H M L}, \beta_{i, M O M}, \beta_{i, S L O}, \beta_{i, C O N T}, \beta_{i, T E R M}$ and $\beta_{i, D E F}$ are estimated coefficients for independent variables and $\alpha_{i}$ is coefficient representing average daily return of particular pension fund type. The last variable $\varepsilon_{i, t}$ stands for residuals of model for pension fund type $i$ in time $t$.

Statistical software R-studio has been used to estimate parameters of model, namely its build-in function for Newey and West's (1987) method, which is implemented in package "Sandwich". Even if some experimental studies such as Jan and Ayub (2019) estimate model parameters by using Artificial Neural Networks, estimation by Newey and West's method has been chosen in this manuscript due to autocorrelation and heteroscedasticity in provided models.

Bollen and Busse four-factor model combines Carhart four factor-model (1997) and findings of Grinblatt and Titman (1994) study. Performance of this model is sensitive to chosen benchmark. Bollen and Busse (2001) decided to add squared market timing factor and extended Bollen and Busse's model (2) to: 


$$
\begin{gathered}
r_{p, t}-r_{f, t}=\propto_{p}+\beta_{i, M K T}\left(r_{m, t}-r_{f, t}\right)+\beta_{i, S M B} S M B_{t}+\beta_{i, H M L} H M L_{t}+\beta_{i, M O M} M M_{t}+ \\
\beta_{i, M K T^{2}}\left(r_{m, t}-r_{f, t}\right)^{2}+\beta_{i, S L O} S L O_{t}+\beta_{i, C O N T} C O N T_{t}+\beta_{i, T E R M} T E R M_{t}+\beta_{i, D E F} D E F_{t}+\varepsilon_{i, t},
\end{gathered}
$$

where all variables are identical to variables in model (1). Variable $\left(r_{m, t}-r_{f, t}\right)^{2}$ is markettiming risk factor and $\beta_{i, M K T^{2}}$ is its coefficients in Newey and West's method. This variable could be statistically significant only for actively managed portfolios.

Based on Titman et al. (2004) and Novy-Marx (2013) studies, original authors of Fama and French three-factor model extended their model and added profitability and investment factors. These factors have been added because higher profitability is associated with higher future returns and higher investments are followed up by lower average returns. Extended Fama and French (2015) five-factor model (3) has following form:

$$
\begin{gathered}
r_{p, t}-r_{f, t}=\propto_{i}+\beta_{i, M K T}\left(r_{m, t}-r_{f, t}\right)+\beta_{i, S M B} S M B_{t}+\beta_{i, H M L} H M L_{t}+\beta_{i, R M W} R M W_{t}+ \\
\beta_{i, C M A} C M A_{t}+\beta_{i, S L O} S L O_{t}+\beta_{i, C O N T} C O N T_{t}+\beta_{i, T E R M} T E R M_{t}+\beta_{i, D E F} D E F_{t}+\varepsilon_{i, t},
\end{gathered}
$$

where all variables are identical to variables in model (1) and variable $R M W_{t}$ represents daily performance calculated as the difference between return of high and low profitability stocks and $C M A_{t}$ is daily investment factor calculated as the difference between return of stocks with low investment ratio and high investment ratio. Variables $\beta_{i, R M W}$ and $\beta_{i, C M A}$ are their coefficients estimated by Newey and West's method.

\section{Results of analysis}

Number of contributors into private pension system in Slovakia reached 1.5 million in September 2019. Once financial crisis has started, second pillar has been open and contributors could leave. This has led to decrease to 1.3 million contributors. Currently, number of contributors is slowly increasing and is expected to reach new maximum by 2020 .

Net asset value managed by private pension system equals 9.8 billion Euro as of September 2019. It is the highest amount reported since the beginning of this system in 2004. It is caused mainly by an increase of nominal salaries in Slovakia (525 Euro in 2004 and 1,068 Euro in the third quarter of 2019) as well as by achieving maximum returns of financial markets in 2019.

Figure 1 shows structure of financial assets per pension fund type from 2012 to 2018. Index funds have shifted from shares in indexed mutual funds to exchange traded funds (ETF). This shift can be explained by broader availability of ETF along with lower fees associated with these assets. After 2012, equity and mixed funds have been transformed from funds with guaranteed nominal value to actual equity and mixed funds. Equity funds have achieved portion of equity securities (stocks and investments in mutual funds) of $70 \%$ compared to initial $7 \%$ out of total assets. Mixed funds have achieved $40 \%$ of equity securities up from initial $5 \%$. Increase in amount of equity securities has caused decrease in bond and money market portions of portfolio. Even though, bonds represent $20 \%$ of assets in equity funds and $50 \%$ in mixed funds. Changes in bond pension funds caused decrease of fixed-term deposits and 


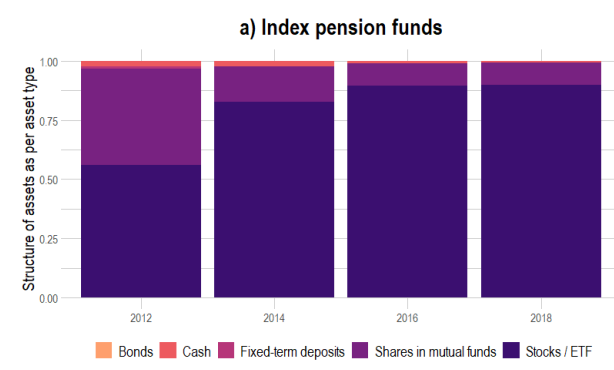

c) Mixed pension funds

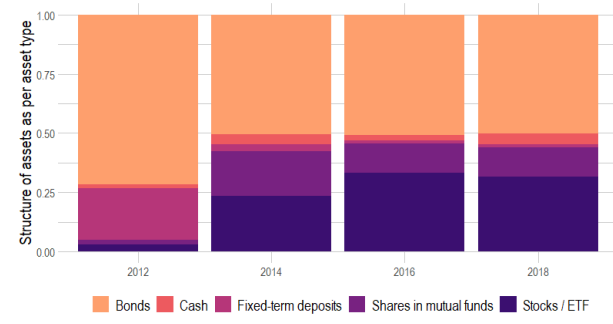

b) Equity pension funds

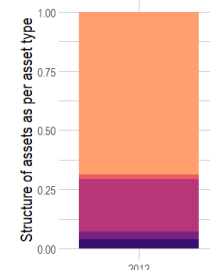

2012

Bonds $\square$ Cash $\square$ Fixed-term deposits

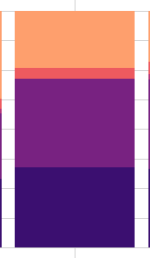

2016

Shares in mutual funds

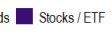

d) Bond pension funds

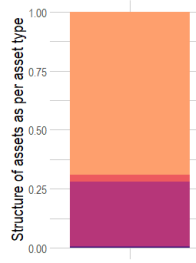

2012

Bonds $\square$ Cash $\square$ Fixed-term deposits $\square$ Shares in mutual funds $\square$ Stocks / ETF

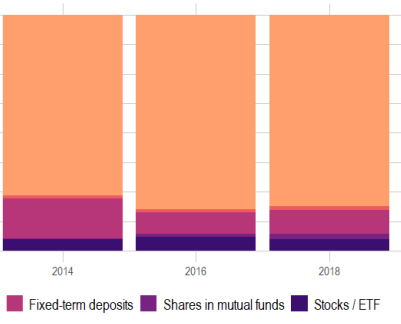

Figure 1. Structure of assets as per asset type for pension funds

their replacement with more risky assets - bonds. This change in bond fund asset structure has been in the range of $10 \%$ out of total assets. Debt securities have been held as trading securities in the past, however, their maturity has extended due to decrease in interest rates and currently part of debt securities is held to maturity. Bond funds currently have $5 \%$ of total assets in equity securities, as well.

Figure 2 shows assets structure from currency point of view. Almost $100 \%$ of assets are denominated in Euro for index and bond funds, $80 \%$ for mixed funs and $60 \%$ for equity

a) Index pension funds

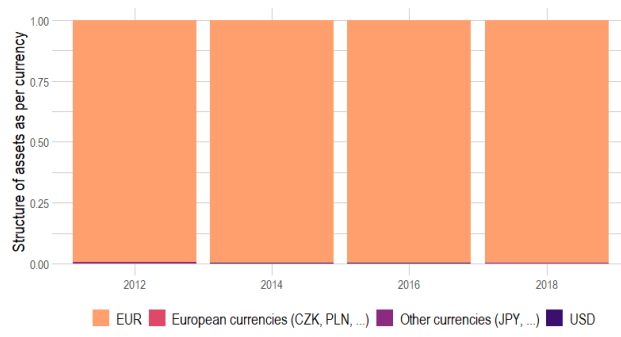

c) Mixed pension funds

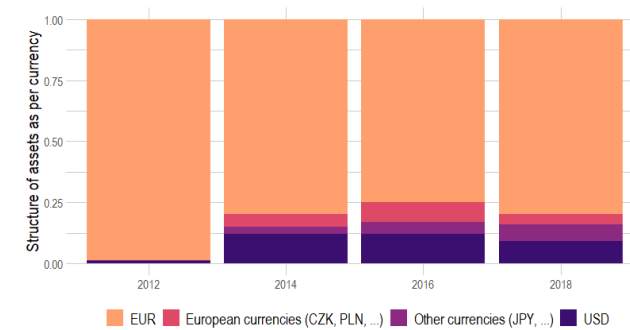

b) Equity pension funds

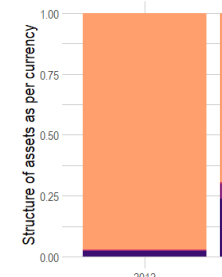

2012

EUR European currencies ICZK, PLN,

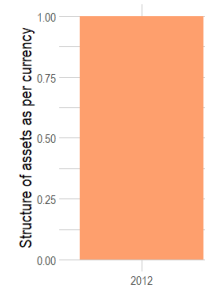

EUR $\square$ European currencies (CZK, PLN, ., d) Bond pension funds

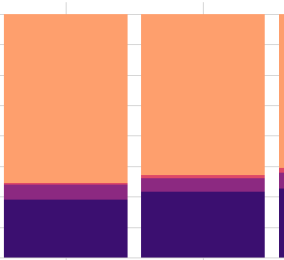

2016

Other currencies (JPY,
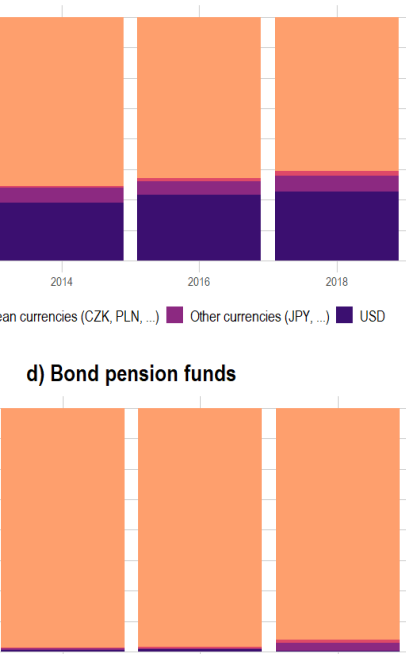

2016

Other currencies (JPY,

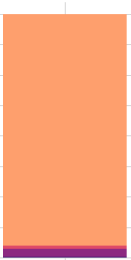

2018

$\square$ USD

Figure 2. Structure of assets as per currency for pension funds 
funds. Other currency in portfolios is U.S. dollar since majority of held equity securities is traded in USD. Investments in USD represent $20 \%$ of assets in equity and mixed funds and $10 \%$ in bond funds. Due to investments into stocks and shares in mutual funds, equity and mixed funds have investments in other world currencies, as well. Major portion of Slovak pension funds' investments, however, remains in Eurozone securities.

Six analysed management companies have managed 23 pension funds during analysed period. There are 19 pension funds as one index fund and three mixed funds have been closed between 2012 and 2019. Figure 3 shows time series of net asset value of different pension funds. For available data, 95\% confidence interval has been calculated and in Figure 1 is shown as grey area. As shown, performance of different pension funds has peaked in 2015 for pension funds with stock portion in portfolio. Another peak has been achieved in 2019 for all pension funds as a result of global economic growth.

Contributions are invested mostly in bond pension funds (74.5\%), in equity funds (13.0\%) and in index funds (11.5\%). The lowest amount of assets is managed by mixed pension funds (1.0\%) which is caused by lack of mixed fund offerings (only two pension funds exist). Mixed pension funds also do not provide any guarantee and achieve average return close to Slovak inflation rate (2.6\% in 1-10 months of 2019). Table 1 provides summary statistics of index, equity, mixed and bond fund samples.

Table 1. Descriptive statistics, final sample of pension funds in Slovakia

\begin{tabular}{|l|c|c|c|c|c|c|}
\hline \multicolumn{1}{|c|}{ Type } & Assets (\%) & $\begin{array}{c}\text { Average } \\
\text { return (\%) }\end{array}$ & $\begin{array}{c}\text { Standard } \\
\text { deviation } \\
(\%)\end{array}$ & $\begin{array}{c}\text { Average } \\
\text { indexed } \\
\text { actual value } \\
\text { of pension } \\
\text { unit }\end{array}$ & $\begin{array}{c}\text { Number } \\
\text { of funds } \\
\text { (maximum) }\end{array}$ & $\begin{array}{c}\text { Average } \\
\text { length } \\
\text { (in years) }\end{array}$ \\
\hline Index & 11.5 & 10.43 & 24.61 & 1.422 & $5(6)$ & 6.0 \\
\hline Equity & 13.0 & 5.49 & 13.19 & 1.191 & $6(6)$ & 7.1 \\
\hline Mixed & 1.0 & 4.08 & 10.72 & 1.132 & $2(5)$ & 4.3 \\
\hline Bond & 74.5 & 1.63 & 4.57 & 1.062 & $6(6)$ & 7.1 \\
\hline
\end{tabular}

Note: own calculation based on data from National Bank of Slovakia.

From September 2012 to September 2019, index funds have achieved average annual return of $10.54 \%$. Return of index funds is significantly higher than return of equity funds $(5.49 \%)$ and return of mixed funds (4.08\%). Fund bearing higher risk report also higher average return. Annual standard deviation indicates that index pension funds bear the highest risk (24.61\%), followed by risk of equity pension funds (13.19\%). Mixed pension funds bear rather low risk $(10.72 \%)$. The lowest average annual return with the lowest volatility have been achieved by bond pension funds (return 1.63\%, standard deviation $4.57 \%$ ). Bond pension fund is considered as guaranteed since management companies have to compensate losses of bond funds from equity. Relatively high risk of index pension funds compared to that of equity pension funds is caused by high portion (between 24-90\% in 2012-2018) of debt securities and money market transactions (Papík, 2017). 
a) Index pension funds

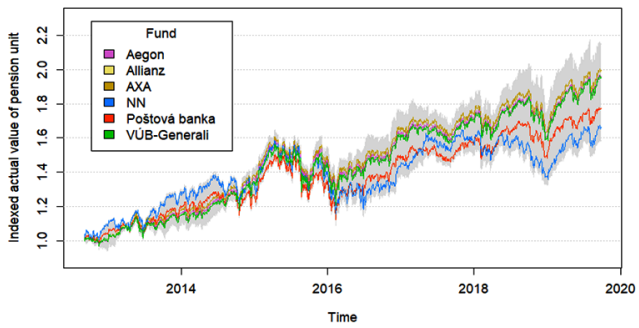

c) Mixed pension funds

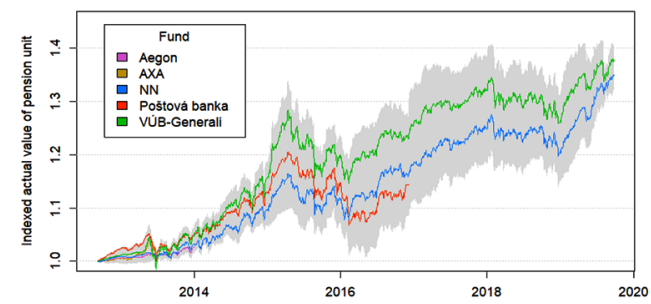

b) Equity pension funds

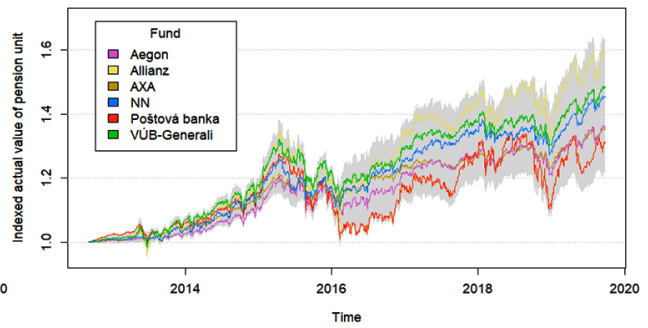

d) Bond pension funds

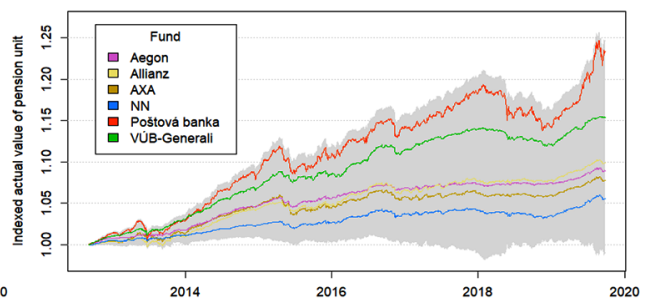

Figure 3. Indexed actual value of pension unit of different pension fund types

Figure 4 contains correlation heatmap among relevant variables. Due to new factors added into three existing models, it has been necessary to test relationships among independent variables. Results prove that both new variables (average $R M W$ returns, average CMA returns) have low correlation to describing values of another model. Slightly higher correlation is between two government regulatory variables SLO and CONT: -0.228 . Correlation analysis shows strong relation between $R M W$ and $H M L$, and between $H M L$ and $C M A$ which has been observed also by Fama and French (2015). Due to independence of factors System left open and Contribution, models (1)-(3) have been extended by these variables.

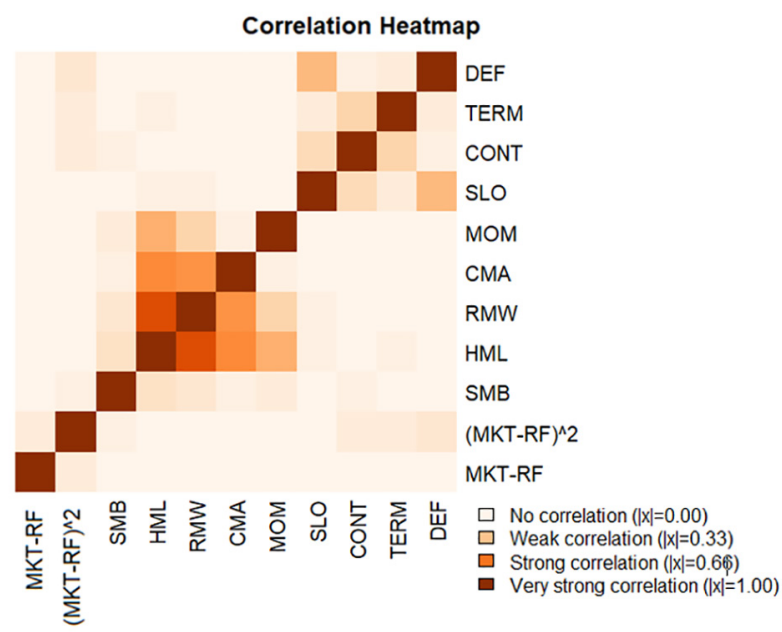

Figure 4. Correlation heatmap 
There is no correlation among bond market factors TERM and DEF and other variables. Correlation between these two variables as well as among other variables is low which has been proved by study of Bektić et al. (2019). Addition of these two variables into models does not increase multicollinearity of these tested models.

Table 2 shows results of three models (1)-(3) with regulatory interventions and bond market factors based on sample of Slovak pension funds. Results of models with regulatory interventions do not prove to have statistically significant daily average returns which is caused by lower impact of individual ability of pension funds $\propto$ to manage their returns. Even though model for index and other funds is not fully comparable due to unused bond market factors, still the highest one-day average returns $\propto$ are achieved by index funds.

Market factor $\beta_{M K T}$ related to difference between fund and European stock market index Euronext 100 arises from different portion of risky assets in portfolio. Therefore, funds with higher portion of stocks or units in mutual funds bear higher risk. Since none $\beta_{M K T}$ variable is higher than one, it can be concluded that Slovak pension funds are less risky than benchmark index used in this manuscript. It can be caused by strict regulations. This means that Slovak funds cannot generate same yields as funds operating in more developed countries. Values of risk component $\beta_{M K T}$ are around 0.80 for index funds, 0.35 for equity funds, 0.19 for mixed funds and 0.01 for bond funds.

Small company effect $\beta_{S M B}$ shows that portfolios have lower exposure of small caps. Portfolio managers prefer larger caps due to stability compared to stocks of small companies.

Momentum from extended Carhart model (1) is statistically significant for bond funds and equity funds, which has been also detected by Kiymaz and Simsek (2017). Their study has also provided lower adjusted R squared compared to that of other portfolios. For each model developed in this manuscript, adjusted $\mathrm{R}$ squared is between $55 \%$ and $80 \%$. This excludes bond funds as models (1)-(3) have described only $22 \%$ to $23 \%$ of estimated values.

Another variable, called managerial ability $\beta_{M K T^{2}}$, is statistically significant only for actively managed pension funds in extended Bollen and Busse model (2). Impact of portfolio manager decision making has had negative effect on analysed funds. Highest negative impact of incorrect portfolio structure has been for equity funds.

Analysis of enhanced Fama and French five-factor model (3) specific variables $\beta_{R M W}$ and $\beta_{C M A}$ also shows that profitability premium (average $R M W$ returns) is higher for more volatile funds as well as for investment premium (average CMA returns). These variables have effect on description of average daily returns in European region which contrary to Fama and French (2017) research.

One out of two regulatory variables is statistically significant for regulatory models (1)(3). Whilst percentage of contribution $\beta_{C O N T}$ is not related to daily average returns, $\beta_{S L O}$ for government intervention has negative impact on dependent variable. During period when pension funds system has been open and contributors could leave the system, pension funds have achieved lower daily return of $0.01 \%$ to $0.03 \%$. The highest impact of this intervention has been reported for index and equity funds (over $0.03 \%$ ). Statistical significance of government intervention $\beta_{S L O}$ variable does not reject hypothesis which assumes existence of Slovak-specific factor bringing instability into pension system. This instability factor has been 


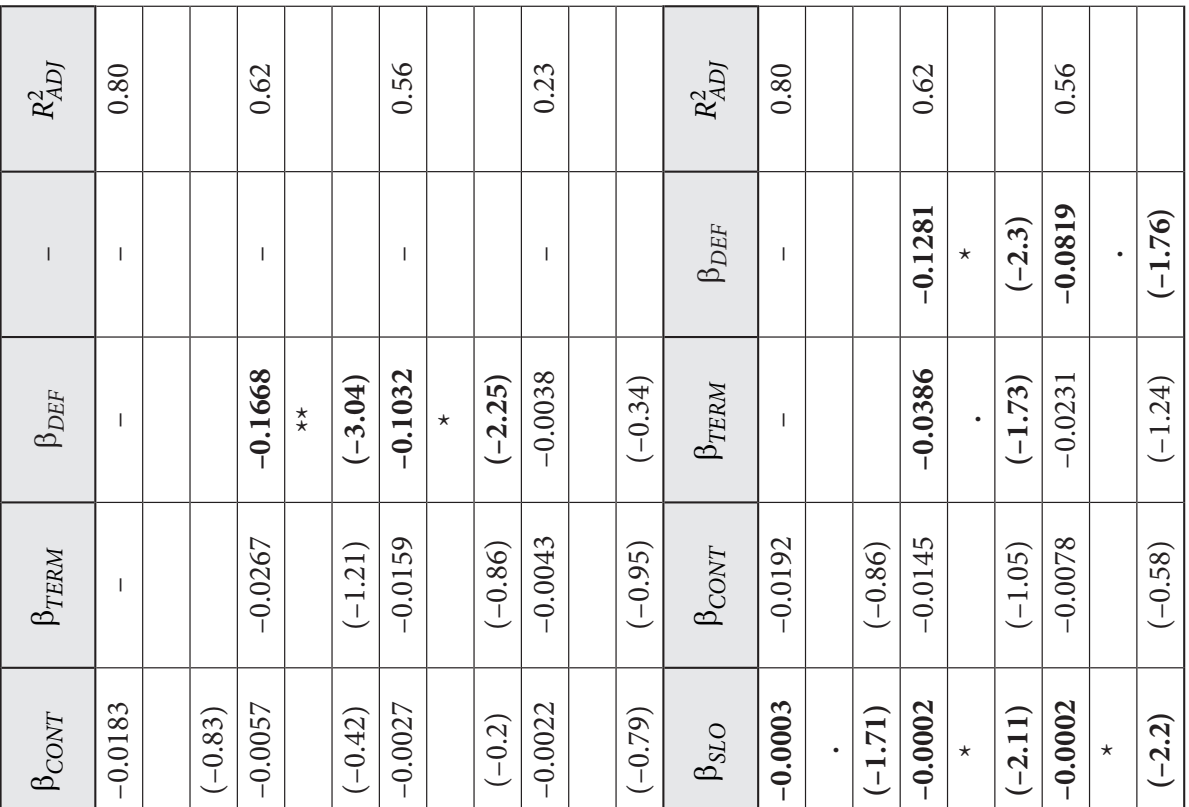

苞

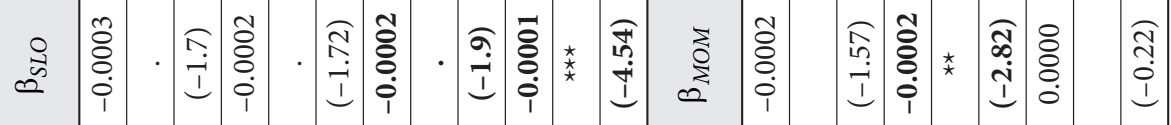

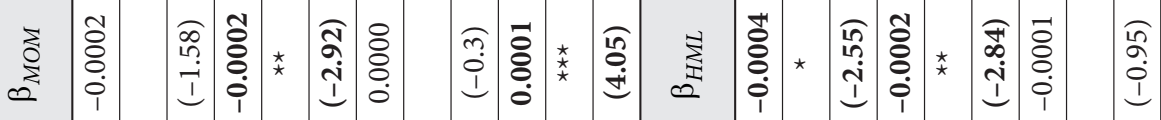

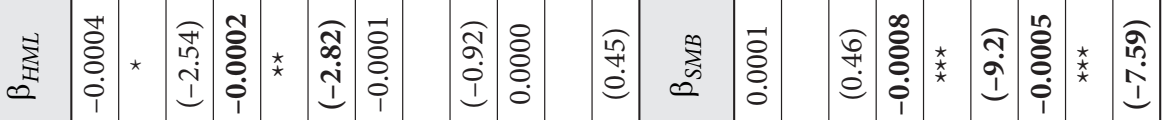

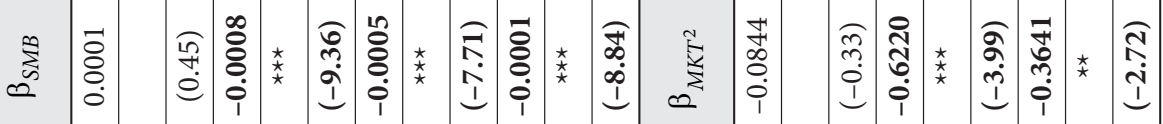

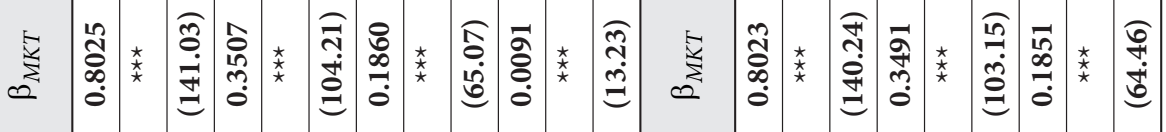

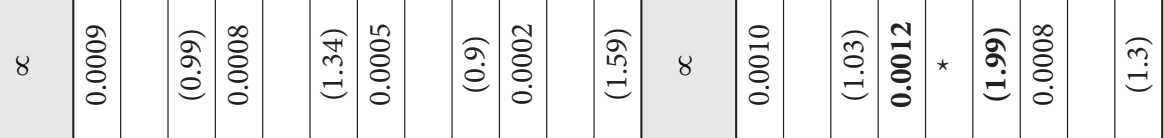

\begin{tabular}{|c|c|c|c|c|c|c|c|c|}
\hline$\frac{\vec{\nabla}}{\dot{z}} \Xi$ & $\stackrel{\varpi}{\tilde{\Xi}}$ & 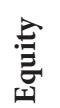 & 总 & $\infty$ & ${ }_{\Sigma}^{\vec{\Sigma}} \widehat{d}$ & 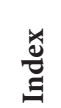 & 莺 & 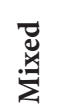 \\
\hline
\end{tabular}




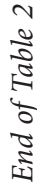

\begin{tabular}{|c|c|c|c|c|c|c|c|c|c|c|c|c|c|c|c|c|c|}
\hline$\tilde{\Sigma}^{\bar{z}}$ & ஸे & & & ॠूरे & $\begin{array}{l}0 \\
\infty \\
0\end{array}$ & & & $\begin{array}{l}\tilde{V} \\
0 \\
0\end{array}$ & & & \begin{tabular}{l}
0 \\
\multirow{2}{*}{} \\
0
\end{tabular} & & & $\stackrel{\overbrace{}}{0}$ & & & \\
\hline 气 & 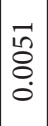 & & 尔 & 离 & 1 & & & \begin{tabular}{c}
$\infty$ \\
0 \\
10 \\
0 \\
\hdashline \\
1 \\
1
\end{tabular} & $\stackrel{\star}{\star}$ & 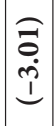 & $\mid$\begin{tabular}{c}
$a$ \\
$\dot{b}$ \\
\hdashline \\
$\dot{0}$ \\
1
\end{tabular} & * & $\begin{array}{c}\widehat{I} \\
\tilde{\widetilde{S}} \\
\stackrel{i}{I}\end{array}$ & $\begin{array}{l}0 \\
0 \\
0 \\
0 \\
0 \\
1\end{array}$ & & $\begin{array}{l}\widehat{\Xi} \\
\hat{0} \\
1\end{array}$ & \\
\hline 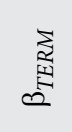 & $\begin{array}{l}0 \\
1 \\
8 \\
0 \\
0 \\
1\end{array}$ & & 命 & 蛋 & 1 & & & 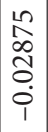 & & $\stackrel{\overparen{n}}{i}$ & $\mid \begin{array}{c}\tilde{b} \\
0 \\
0 \\
0 \\
1\end{array}$ & & 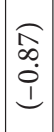 & $\begin{array}{l}\hat{\sigma} \\
\tilde{\delta} \\
\dot{0} \\
\dot{1}\end{array}$ & & $\begin{array}{l}\widehat{I} \\
\infty \\
0 \\
1 \\
1\end{array}$ & \\
\hline $\begin{array}{l}5 \\
0 \\
0 \\
0\end{array}$ & 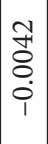 & & $\stackrel{\overparen{1}}{I}$ & $\begin{array}{c}\bar{z} \\
0 \\
0 \\
0\end{array}$ & $\begin{array}{l}0 \\
0 \\
0 \\
0 \\
0\end{array}$ & & $\begin{array}{l}\widehat{T} \\
\hat{N} \\
0 \\
1 \\
1\end{array}$ & $\begin{array}{l}-1 \\
0 \\
0 \\
0 \\
0 \\
1\end{array}$ & & $\begin{array}{r}\text { If } \\
\stackrel{1}{i} \\
\text { I }\end{array}$ & 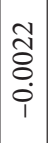 & & 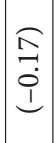 & $\begin{array}{l}n \\
0 \\
8 \\
0 \\
0 \\
1\end{array}$ & & $\begin{array}{l}\widehat{0} \\
\tilde{n} \\
0 \\
1 \\
1\end{array}$ & 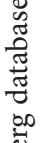 \\
\hline ల్చ & $\begin{array}{l}0 \\
\\
0 \\
0 \\
0 \\
1\end{array}$ & 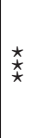 & & $\stackrel{\substack{\omega \\
\infty}}{\infty}$ & 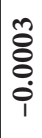 & $\cdot$ & 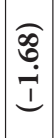 & $\begin{array}{c}1 \\
\delta \\
0 \\
0 \\
i \\
1\end{array}$ & . & 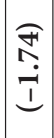 & $\mid \begin{array}{c}1 \\
\delta \\
0 \\
0 \\
1\end{array}$ & . & 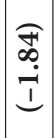 & $\begin{array}{l}\bar{\delta} \\
\text { o. } \\
\dot{0} \\
1\end{array}$ & 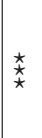 & 苞 & 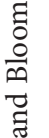 \\
\hline$\underset{\infty}{\stackrel{\Sigma}{\Sigma}}$ & 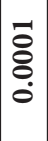 & 齐 & త6 & ¿্য & $\begin{array}{l}0 \\
8 \\
8 \\
0 \\
0 \\
1\end{array}$ & * & $\widehat{\vec{i}}$ & $\begin{array}{l}\overrightarrow{8} \\
8 \\
0 \\
0 \\
1\end{array}$ & & 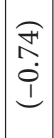 & $\begin{array}{l}\overrightarrow{0} \\
8 \\
0 \\
0 \\
1\end{array}$ & & $\begin{array}{l}\widehat{\sigma} \\
i \\
0 \\
i \\
1\end{array}$ & $\begin{array}{l}8 \\
8 \\
0 \\
0 \\
0\end{array}$ & & $\begin{array}{l}\widehat{a} \\
\mathfrak{n} \\
e\end{array}$ & 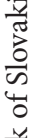 \\
\hline$a^{\exists}$ & \begin{tabular}{l}
8 \\
\hdashline \\
8 \\
0 \\
0
\end{tabular} & & ণ্ডি & $\sum^{3}$ & $\begin{array}{l}\infty \\
0 \\
8 \\
0 \\
0\end{array}$ & * & 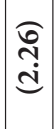 & $\begin{array}{l}\overrightarrow{8} \\
\dot{8} \\
0 \\
\dot{0}\end{array}$ & & $\begin{array}{l}\mathfrak{d} \\
\stackrel{1}{e} \\
\stackrel{c}{c}\end{array}$ & $\mid \begin{array}{l}0 \\
\delta \\
0 \\
0 \\
0\end{array}$ & & $\stackrel{\stackrel{o}{o}}{\stackrel{\Xi}{\Xi}}$ & o̊ & 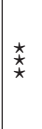 & 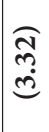 & 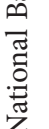 \\
\hline స్టి & $\begin{array}{l}\tilde{8} \\
0 \\
0 \\
0 \\
1\end{array}$ & 齐 & $\begin{array}{l}0 \\
0 \\
0 \\
1 \\
1\end{array}$ & 亲 & 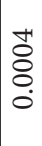 & & 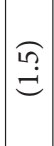 & $\begin{array}{l}\overrightarrow{0} \\
0 \\
0 \\
0 \\
1\end{array}$ & & 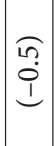 & \begin{tabular}{|l|}
$\overrightarrow{8}$ \\
0 \\
0 \\
0
\end{tabular} & & $\begin{array}{l}\widehat{\vec{b}} \\
\stackrel{e}{e}\end{array}$ & 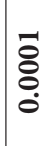 & . & $\stackrel{\substack{n\\
}}{=}$ & 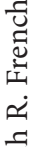 \\
\hline$\infty^{\tilde{E}}$ & $\frac{\bar{m}}{\stackrel{a}{+}}$ & 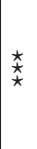 & 守 & స్టి & $\begin{array}{l}\text { סे } \\
8 \\
0\end{array}$ & & $\begin{array}{l}\widehat{\tilde{n}} \\
\stackrel{0}{0}\end{array}$ & $\begin{array}{l}\infty \\
0 \\
0 \\
0 \\
0 \\
1\end{array}$ & 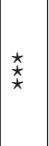 & 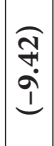 & $\begin{array}{l}n \\
0 \\
0 \\
0 \\
0 \\
1 \\
1\end{array}$ & 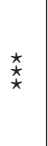 & 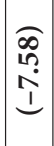 & $\begin{array}{l}\overline{8} \\
\text { ô } \\
\text { i }\end{array}$ & $\underset{x}{*}$ & $\begin{array}{c}\text { 苟 } \\
\infty \\
0 \\
1 \\
1\end{array}$ & 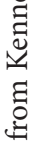 \\
\hline$e^{\frac{5}{3}}$ & \begin{tabular}{|c|}
1 \\
0 \\
0 \\
0 \\
0 \\
0
\end{tabular} & 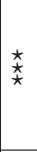 & 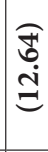 & $e^{5}$ & 命 & 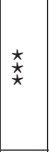 & 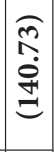 & $\begin{array}{l}\infty \\
0 \\
10 \\
0 \\
0 \\
0\end{array}$ & $\stackrel{\star}{\star}$ & $\begin{array}{l}\widehat{\tilde{o}} \\
\dot{0} \\
\stackrel{\Xi}{\Xi}\end{array}$ & $\begin{array}{l}\infty \\
1 \\
\infty \\
0 \\
0 \\
0\end{array}$ & $\stackrel{\star \star}{\star}$ & 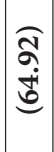 & 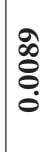 & $\underset{⿱ 亠 乂}{\star}$ & 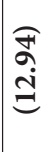 & 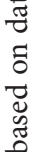 \\
\hline 8 & $\begin{array}{l}\tilde{8} \\
\delta \\
0 \\
0\end{array}$ & $\star$ & $\stackrel{\tilde{n}}{\stackrel{\tilde{d}}{d}}$ & 8 & $\begin{array}{l}\infty \\
8 \\
8 \\
0 \\
0\end{array}$ & & $\stackrel{\widehat{a}}{\grave{e}}$ & \begin{tabular}{|l|}
$\infty$ \\
0 \\
0 \\
0 \\
0 \\
0
\end{tabular} & & 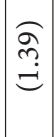 & \begin{tabular}{|l|}
0 \\
0 \\
8 \\
0 \\
0 \\
0
\end{tabular} & & $\begin{array}{c}\widehat{E} \\
\infty \\
e \\
e\end{array}$ & $\begin{array}{l}0 \\
\delta \\
\delta \\
0 \\
0\end{array}$ & & $\stackrel{\overbrace{}}{\stackrel{\overbrace{}}{\leftrightarrows}}$ & 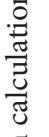 \\
\hline$\frac{\vec{\nabla}}{\stackrel{\Sigma}{\Sigma}} \widehat{d}$ & & बేँ & & 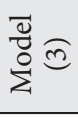 & & 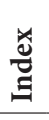 & & & 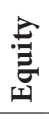 & & & 荿 & & & $\bar{\Xi}$ & & 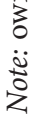 \\
\hline
\end{tabular}


introduced into system from the outside as a state intervention changing whole concept of private pension fund system from mandatory to optional.

Among bond market factors, variable term premium TERM has not been statistically significant for neither model from (1) to (3) nor for any kind of pension fund type. Variable default premium $D E F$ has been significant for all models from (1) to (3). $D E F$ variable is significant for equity and mixed funds which, unlike bond funds, invest more into corporate bonds with higher risk premium. Bond funds are less sensitive to changes in risk premium as they are formed by government bonds from Eurozone, treasury bills and mortgage bonds.

\section{Discussion}

All models in this manuscript have statistical dependence with benchmark for market risk for different types of funds. Pension funds in Slovakia have achieved lower level of risk than benchmark, which is also contradictory to other studies. Momentum dependency for equity and bond pension funds has been confirmed by models developed in this manuscript in terms of specific attributes. This finding is in line with other studies. Similar statistical significance has been proved also for managerial ability variables which was significant only for actively managed portfolios. This variable has had negative impact on performance of these portfolios.

Results of this manuscript can confirm that interventions of portfolio managers do not bring in any extra yields to contributors in the long run. Contributors should therefore prefer passively managed pension funds. Analysis of Fama and French five-factor model has shown that profitability premium is higher for more volatile funds and well as investments premium is.

Despite using bond market factors, bond funds have achieved adjusted $\mathrm{R}$ squared of only approximately $22 \%$, which is significantly lower than adjusted R squared achieved for another pension funds. Several other studies have also shown that current models might not be accurate for performance analysis of funds with significant fixed income portion. Despite weaker results of analysis, this manuscript has proved that with addition of describing variables of bond market, regulatory interventions affect daily returns of portfolios even more.

By extending models (1) - (3) with new variables (System left open and Contribution), these models have become dependent on regulatory interventions. Even though contribution variable has not been statistically significant, during periods when pension system has been left open, pension funds have achieved significantly lower returns which is in line with studies from Poland.

This manuscript has not proved increased risk of portfolio during the same period. Regulators should therefore limit fundamental interventions of pension system to minimum and should only focus on minor changes of the system. It can be concluded that there should be consensus across whole political spectrum about the existence and conditions of the second pillar. Recurring regulation interventions should not take place in Slovakia as it has happened over past years.

Separate limitation of this manuscript is limited number of pension funds in Slovakia. Another limitation is also relatively short time period analysed which is also limitation of 
other studies. Pension funds are still relatively new phenomenon in CEE countries. Should authors try to follow any local specifics resulting from local legislation, their studies become very complex and difficult to compare in terms of cross-country comparisons. Therefore, it is suggested not to combine different pension systems within a single model. If a single model is indeed necessary to use, it should be able to differentiate values for individual countries.

Main contribution of this manuscript is that it is a pioneering research studying Slovak pension funds also through the impact of regulatory interventions. Other studies have so far focused only on analysis of market parameters and have excluded regulatory interventions.

Results of this manuscript may not be only utilized in similar studies of the second pillar and regulatory interventions in other countries, but can possibly contribute to potential extension of existing asset pricing models to incorporate regional specifications, regulatory interventions and other variables that are currently not included.

\section{Conclusions}

Reforms, that have implemented multi-pillar pension system during mid-1990's and early 2000's in CEE, aimed to achieve long-term sustainability of public finances. Public finances have been threatened by negative demographic developments. For these new pillars of pension system to fulfil their purpose, it is essential that these funds achieve sufficient returns in long-term period. In ideal case, these funds should also achieve higher returns than stock markets. Despite voluntariness of participation in the second pillar, number of contributors has increased during last two years by 200000 contributors to overall 1650000 contributors in Slovakia. This increase in number of contributors indicates that contributors are indeed aware of necessity of individual savings for retirement. Participation in the second pillar becomes extremely important as population in Europe is aging and governments are tasked to develop sustainable public finances in the long run. Governments should therefore encourage their citizens to participate in the second pillar as it is capable of generating higher returns than those of compulsory first pillar, which has achieved low average 3.5\% growth during period 2009 and 2018.

Not each government intervention, though, contributes to increased stability of pension system and savings in it. As this manuscript has showed that every government intervention has caused decrease in pension funds returns by few percent. Government interventions into Slovak pension system have been caused by changes of government and by political disagreement about the 2003 reform of pension system. Consensus about pension system across whole political spectrum is therefore crucial. It is important that already implemented reforms by previous administrations are not adjusted by following administrations. Such ongoing adjustments of pension system impose negative impact on returns of these funds and hence directly impact the amount of old age pensions paid to contributors. From the long-run point of view, such interventions into pension system significantly impact purchasing power of pensioners and also public finances due to pressure to provide sufficient retirement pay.

There are many existing studies about CEE countries dealing with performance of pension funds. This manuscript has innovatively applied models on the specifications of Slovak 
pension system and considering regulatory as well as bond market factors. Such an analysis has not been conducted on Slovak pension system yet. This manuscript has therefore confirmed results of other studies from the CEE region considering local Slovak specifications. Results of this manuscript can be generalized and applied to any other CEE country as other existing studies have also confirmed negative impact of government interventions on performance of pension funds.

Possible limitation of this study could be shorter time period analysed and lower number of funds included in dataset. This limitation is caused by shorter period of existence of these pension funds in Slovakia, as well as by lower number of contributors into pension system than in other CEE countries. Another limitation is relatively weak performance of models applied to portfolios with high amount of fixed income securities. Despite extension of existing models with variables describing bond market factors and despite statistical significance of these variables, adjusted $\mathrm{R}$ squared of tested model has not improved. It is therefore necessary to continue in research of performance models and focus more on the bond element of portfolios. It is essential to explain characteristics of bond factors not only via term and default premium, but also other characteristics like mark-to-mark valuation vs. held to maturity valuation.

\section{Disclosure statement}

The authors (Mário Papík and Lenka Papíková) have NO affiliations with or involvement in any organization or entity with any financial interest (such as honoraria; educational grants; participation in speakers' bureaus; membership, employment, consultancies, stock ownership, or other equity interest; and expert testimony or patent-licensing arrangements), or non-financial interest (such as personal or professional relationships, affiliations, knowledge or beliefs) in the subject matter or materials discussed in this manuscript.

\section{Acknowledgement}

This manuscript was funded by the Faculty of Management, Comenius University in Bratislava, Slovakia.

\section{References}

Adami, R., Gough, O., Mukherjee, S., \& Sivaprasad, S. (2014). An empirical analysis of the performance of pension funds: Evidence from UK. Studies in Economics and Finance, 31(2), 141-155. https://doi.org/10.1108/SEF-10-2012-0118

Alam, M., \& Ansari, V. A. (2020). Do mutual fund managers' possess style liquidity timing abilities? International Journal of Emerging Markets. https://doi.org/10.1108/IJOEM-02-2020-0195

Alda, M., \& Ferruz, L. A. (2012). The role of fees in pension fund performance. Evidence from Spain. Finance a úvěr - Czech Journal of Economics and Finance, 62(6), 518-535.

Ali, F., Khurram, M. U., \& Jiang, Y. (2019). The five-factor asset pricing model tests and profitability and investment premiums: Evidence from Pakistan. Emerging Markets Finance and Trade. https://doi.org/10.1080/1540496X.2019.1650738 
Antolin, P. (2008). Pension fund performance (OECD Working Papers on Insurance and Private Pensions, 20). OECD publishing. https://doi.org/10.1787/19936397

Azizi, H. R., Pakmaram, A., Rezaei, N., \& Abdi, R. (2020). Presenting a model for portfolio risk premium assessment: Evidence from the Tehran stock exchange. International Journal of Nonlinear Analysis and Applications, 11(2), 21-30.

Bauer, R., \& Kicken, L. (2008). The pension fund advantage: Are Canadians overpaying their mutual funds? Journal of Pension Management, 1(1), 64-71. https://ssrn.com/abstract=1290645

Bektić, D., Wenzler, J., Wegener, M., Schiereck, D., \& Spielmann, T. (2019). Extending Fama-French factors to corporate bond markets. The Journal of Portfolio Management, 45(3), 141-158. https://doi.org/10.3905/jpm.2019.45.3.141

Bektić, D., Hachenberg, B., \& Schiereck, D. (2020). Factor-based investing in government bond markets: A survey of the current state of research. Journal of Asset Management, 21(2), 94-105. https://doi.org/10.1057/s41260-020-00156-3

Blake, D., Lenhmann, B., \& Timmermann, A. (2002). Performance clustering and incentives in the UK pension fund industry. Journal of Asset Management, 3, 173-194. https://doi.org/10.1007/978-3-319-30794-7_5

Bielawska, K., Chloń-Domińczak, A., \& Stańko, D. (2017). Retreat from mandatory pension funds in countries of the Eastern and Central Europe in result of financial and fiscal crisis: Causes, effects and recommendations for fiscal rules (MPRA Paper, 83345, pp. 1-106). Munich Personal RePEC Archive. https://mpra.ub.uni-muenchen.de/id/eprint/83345

Bollen, N. P., \& Busse, J. A. (2001). On the timing ability of mutual fund managers. Journal of Finance, 56(3), 1075-1094. https://doi.org/10.1111/0022-1082.00356

Boon, L. N., Briere, M., \& Rigot, S. (2018). Regulation and pension fund risk-taking. Journal of International Money and Finance, 84, 23-41. https://doi.org/10.1016/j.jimonfin.2018.01.005

Boubakri, N., Cosset, J. C., \& Grira, J. (2016). Sovereign wealth funds targets selection: A comparison with pension funds. Journal of International Financial Markets, Institutions and Money, 42, 60-76. https://doi.org/10.1016/j.intfin.2016.01.004

Brousseau, C. (2015). The pricing of liquidity risk and accounting quality in Canada. Accounting and Finance Research, 4(4), 127-139. https://doi.org/10.5430/afr.v4n4p127

Casey, B. (2014). From Pension Funds to Piggy Banks: (Perverse) consequences of the stability and growth pact since the crisis. International Social Security Review, 67(1), 27-48. https://doi.org/10.1111/issr.12029

Carhart, M. M. (1997). On persistence in mutual fund performance. Journal of Finance, 52(1), 57-82. https://doi.org/10.1111/j.1540-6261.1997.tb03808.x

Cerami, A. (2011). Ageing and the politics of pension reforms in Central Europe, South-Eastern Europe and the Baltic States. International Journal of Social Welfare, 20(4), 331-343. https://doi.org/10.1111/j.1468-2397.2010.00748.x

Choi, J., \& Kim, Y. (2018). Anomalies and market (dis)integration. Journal of Monetary Economics, 100, 16-34. https://doi.org/10.1016/j.jmoneco.2018.06.003

Chovancová, B., \& Bačišin, V. (2005). Kolektívne investovanie: podielové a penzijné fondy. 1. Bratislava: IURA Edition.

Chovancová, B., Hudcovský, J., \& Kotasková, A. (2019). The impact of stocks and bonds on pension fund performance. Journal of Competitiveness, 11(2), 22-35. https://doi.org/10.7441/joc.2019.02.02

Clare, A., Cuthbertson, K., \& Nitzsche, D. (2010). An empirical investigation into the performance of UK pension fund managers. Journal of Pension Economics and Finance, 9(4), 533-547. https://doi.org/10.1017/S1474747209990138 
Cremers, M., Petajisto, A., \& Zitzewitz, E. (2012). Should benchmark indices have alpha? Revisiting performance evaluation. Critical Finance Review, 2, 1-48.

https://www.dartmouth.edu/ ericz/benchmarks.pdf

Drahokoupil, J., \& Domonkos, S. (2012). Averting the funding-gap crisis: East European pension reforms after 2008. Global Social Policy, 12(3), 283-299. https://doi.org/10.1177/1468018112455653

Draženović, B. O., Hodžić, S., \& Maradin, D. (2019). Efficiency of mandatory pension funds: Case of Croatia. South East European Journal of Economics and Business, 14(2), 82-94. https://doi.org/10.2478/jeb-2019-0015

Égert, B. (2012). The impact of changes in second pension pillars on public finances in Central and Eastern Europe. Economic Systems, 37(3), 473-491. https://doi.org/10.1016/j.ecosys.2013.01.002

Fama, F. E., \& French, K. R. (1993). Common risk factors in the returns on stocks and bonds. Journal of Financial Economics, 33(1), 3-56. https://doi.org/10.1016/0304-405X(93)90023-5

Fama, F. E., \& French, K. R. (2015). A five-factor asset pricing model. Journal of Financial Economics, 116(1), 1-22. https://doi.org/10.1016/j.jfineco.2014.10.010

Fama, F. E., \& French, K. R. (2017). International tests of a five-factor asset pricing model. Journal of Financial Economics, 123(3), 441-463. https://doi.org/10.1016/j.jfineco.2016.11.004

Galinienè, B., \& Butvilas, A. (2010). Analysis of the capital cost impact on share value. Technological and Economic Development of Economy, 16(1), 126-142. https://doi.org/10.3846/tede.2010.08

Grinblatt, M., \& Titman, S. (1994). A study of monthly mutual fund returns and performance evaluation techniques. Journal of Financial and Quantitative Analysis, 29(3), 419-444. https://doi.org/10.2307/2331338

Guardiancich, I. (2013). Pension reforms in Central, Eastern, and Southeastern Europe: From post-Socialist transition to the global financial crisis ( $1^{\text {st }} \mathrm{ed}$.). Routledge/EUI studies in the political economy of the welfare state. Routledge. https://www.routledge.com/Pension-Reforms-in-Central-Eastern-andSoutheastern-Europe-From-Post-Socialist/Guardiancich/p/book/9781138822214

Jan, M. N., \& Ayub, U. (2019). Do the FAMA and FRENCH Five-Factor model forecast well using ANN? Journal of Business Economics and Management, 20(1), 168-191. https://doi.org/10.3846/jbem.2019.8250

Janać, J., Rentková, K., \& Stanko, P. (2016, April). The implementation of the second pillar pension in Serbia. In $15^{\text {th }}$ International Scientific Conference for PhD students and young researchers: Management in Theory and Practice (pp. 255-262). Slovakia, Bratislava.

Jegadeesh, N., \& Titman, S. (1993). Returns to buying winners and selling losers: Implications for stock market efficiency. Journal of Finance, 48(1), 65-91. https://doi.org/10.1111/j.1540-6261.1993.tb04702.x

Jensen, M. C. (1968). The performance of mutual funds in the period 1945-1964. Journal of Finance, 23(2), 389-416. https://doi.org/10.2139/ssrn.244153

Josifidis, K., Hall, J. B., Supic, N., \& Pucar, E. B. (2015). The European welfare state regimes: Questioning the typology during the crisis. Technological and Economic Development of Economy, 21(4), 277-595. https://doi.org/10.3846/20294913.2015.1055612

Kabašinskas, A., Šutiené, K., Miloš, K., \& Valakevičius, E. (2017). The risk-return profile of Lithuanian private pension funds. Economic Research-Ekonomska Istraživanja, 30(1), 1611-1630. https://doi.org/10.1080/1331677X.2017.1383169

Kaya, E. (2020). Relative performances of asset pricing models for BIST 100 index. Spanish Journal of Finance and Accounting/Revista Espanola de Filanciacion y Contabilida. https://doi.org/10.1080/02102412.2020.1801169

Kiymaz, H., \& Simsek, K. D. (2017). The performance of US-based emerging market mutual funds. Journal of Capital Markets Studies, 1(1), 58-73. https://doi.org/10.1108/JCMS-10-2017-003 
Khorana, A., Servaes, H., \& Tufano, P. (2007). Mutual fund fees around the world (HBS Finance Working Paper, 901023). https://doi.org/10.1093/rfs/hhn042

Kurach, R. (2019). Do they beat the market in the new regulatory environment - the case of Polish pension funds. Economic Research-Ekonomska Istraživanja, 32(1), 370-383. https://doi.org/10.1080/1331677X.2018.1561319

Kurach, R., Kuśmierczyk, P., \& Papla, D. (2020). Risk reduction in two-pillar mandatory pension system under regulatory constraints: Simulation-based evidence from Poland. Applied Economics Letters, 28(3), 191-195. https://doi.org/10.1080/13504851.2020.1740154

Leite, P., \& Cortez, M. C. (2014). Style and performance of international socially responsible funds in Europe. Research in International Business and Finance, 30, 248-267. https://doi.org/10.1016/j.ribaf.2013.09.007

Madrid, R. L. (2003). Retiring the State: The politics of pension privatization in Latin America and beyond. Stanford University Press. https://doi.org/10.1017/S1537592704700377

Marti-Ballester, C. P. (2019). The role of mutual funds in the sustainable energy sector. Business Strategy and the Environment, 28(6), 1107-1120. https://doi.org/10.1002/bse.2305

Martí-Ballester, C. P. (2020) Examining the financial performance of pension funds focused on sectors related to sustainable development goals. International Journal of Sustainable Development \& World Ecology, 27(2), 179-191. https://doi.org/10.1080/13504509.2019.1678532

Matek, P., Lukač, M., \& Repač, V. (2015). Performance appraisal of Croatian mandatory pension funds (Effectus - Working Paper Series 0004). Effectus - University College for Law and Finance.

Medaiskis, T., \& Gudaitis, T. (2017). Evaluation of second pillar pension funds' supply and investment strategies in Baltics. Journal of Business Economics and Management, 18(6), 1174-1192. https://doi.org/10.3846/16111699.2017.1381145

Meštan, M., Kubaška, P., \& Králik, I. (2016, September). Evaluating financial performance of pension funds in Slovakia. In International Scientific Conference FERNSTAT 2016 (pp. 105-114). Bánska Bystrica.

Mitková, L. (2016). Europe’s ageing population and the gender pension gap. In Európska ekonomická integrácia v kontexte aktuálneho vývoja a výziev pre členské štáty Európskej únie (pp. 68-80). Wolter Kluver.

Naczyk, M., \& Domonkos, S. (2016). The financial crisis and varieties of pension privatization reversals in Eastern Europe. Governance, 29(2), 167-184. https://doi.org/10.1111/gove.12159

Newey, W. K., \& West, K. D. (1987). A simple, positive semi-definite, heteroskedasticity and autocorrelation consistent covariance matrix. Econometrica, 55(3), 703-708. https://doi.org/10.2307/1913610

Novy-Marx, R. (2013). The other side of value: The gross profitability premium. Journal of Financial Economics, 108(1), 1-28. https://doi.org/10.1016/j.jineco.2013.01.003

Orenstein, M. A. (2011). Pension privatization in crisis: Death or rebirth of a global policy trend? International Social Security Review, 64(3), 65-80. https://doi.org/10.1111/j.1468-246X.2011.01403.x

Papík, M., \& Kajanová, J. (2016). The influence of Slovak pension reform on the second pillar during the Financial Crisis. In 29th IBIMA Conference Vision 2020: Innovation Management, Development Sustainibility and Competitive Economic Growth (pp. 793-800). Austria, Vienna.

Papík, M. (2017). Composition of equity and mixed pension funds in Slovakia. Oeconomia Copernicana, 8(1), 51-64. https://doi.org/10.24136/oc.v8i1.4

Portier, F. (2018). The instability of market economies. Revue de L'Ofce, 157(3), 225-233. https://doi.org/10.3917/reof.157.0225

Price, W., \& Rudolph, H. P. (2013). Reversal and reduction, resolution and reform: Lessons from the financial crisis in Europe and Central Asia. The World Bank. 
Roy, R., \& Shijin, S. (2018). A six-factor asset pricing model. Borsa Istanbul Review, 18(3), 205-217. https://doi.org/10.1016/j.bir.2018.02.001

Saxunová, D., \& Chorvatovičová, L. (2018). Management of labour force movement applied in Slovakia. Social and Economic Revue, 16(2), 35-43.

Silva, F., \& Cortez, M. C. (2016). The performance of US and European green funds in different market conditions. Journal of Cleaner Production. 135, 558-566. https://doi.org/10.1016/j.jclepro.2016.06.112

Sharpe, W. F. (1964). Capital asset prices: A theory of market equilibrium under conditions of risk. Journal of Finance, 19(3), 425-442. https://doi.org/10.1111/j.1540-6261.1964.tb02865.x

Sharpe, W. F. (1994). The Sharpe ratio. Journal of Portfolio Management, 21(1), 49-58. https://doi.org/10.3905/jpm.1994.409501

Sha, Y., \& Gao, R. (2019). Which is the best: A comparison of asset pricing factor models in Chinese mutual fund industry. Economic Modelling, 83, 8-16. https://doi.org/10.1016/j.econmod.2019.09.016

Sortino, F. A., \& Van Der Meer, R. (1991). Downside risk-capturing what's at stake in investment situations. Journal of Portfolio Management, 17(4), 27-31. https://doi.org/10.1080/00036840601019075

Titman, S., Wei, K., \& Xie, F. (2004). Capital investments and stock returns. Journal of Financial and Quantitative Analysis, 39(4), 677-700. https://doi.org/10.1017/S0022109000003173

Tonks, I. (2005). Performance persistence of pension-fund managers. Journal of Business, 78(5), 19171942. https://doi.org/10.1086/431447

Treynor, J. (1965). How to rate management of investment funds. Harvard Business Review, 43(1), 63-75.

Witkowska, D., Kompa, K., \& Mentel, G. (2019). The effect of government decisions on the efficiency of the investment funds market in Poland. Journal of Business Economics and Management, 20(3), 573-594. https://doi.org/10.3846/jbem.2019.9861

Zaremba, A., Czapkiewicz, A., Szczygielski, J. J., \& Kaganov, V. (2019). An application of factor pricing models to the Polish stock market. Emerging Markets Finance and Trade, 55(9), 2039-2056. https://doi.org/10.1080/1540496X.2018.1517042 